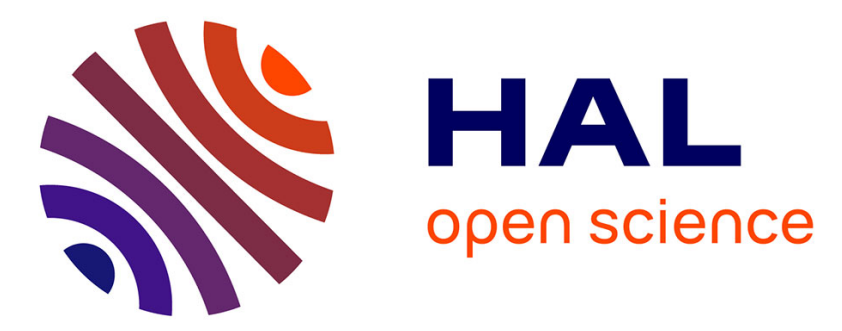

\title{
Information Systems Curriculum in an Australian University: Past Developments and Future Directions
}

Arthur Tatnall, Stephen Burgess

\section{To cite this version:}

Arthur Tatnall, Stephen Burgess. Information Systems Curriculum in an Australian University: Past Developments and Future Directions. 11th IFIP World Conference on Computers in Education (WCCE), Jul 2017, Dublin, Ireland. pp.463-472, 10.1007/978-3-319-74310-3_47 . hal-01762912

\section{HAL Id: hal-01762912 \\ https://hal.inria.fr/hal-01762912}

Submitted on 10 Apr 2018

HAL is a multi-disciplinary open access archive for the deposit and dissemination of scientific research documents, whether they are published or not. The documents may come from teaching and research institutions in France or abroad, or from public or private research centers.
L'archive ouverte pluridisciplinaire HAL, est destinée au dépôt et à la diffusion de documents scientifiques de niveau recherche, publiés ou non, émanant des établissements d'enseignement et de recherche français ou étrangers, des laboratoires publics ou privés. 


\title{
Information Systems Curriculum in an Australian University: Past Developments and Future Directions
}

\author{
Arthur Tatnall and Stephen Burgess \\ Victoria University, Australia \\ Arthur.Tatnall@vu.edu.au, Stephen.Burgess@vu.edu.au
}

\begin{abstract}
In this paper we describe the development of Information Systems (IS) curricula in the Business Faculty of an Australian university over the last 40 years, but then look at how what has happened is likely to affect future developments. The paper looks at how curriculum content was added over the years when it covered what was considered, at the time, to be important new material. In many cases in later years this material became mainstream and so there was no need to include it in IS courses. An example of this is eCommerce which was an extremely important new area in the late 1990s that was developed into new IS subjects and new undergraduate and postgraduate degree courses. By the mid-2000s, however, everyone was using eCommerce and it was included in many other subject areas, making it no longer necessary to be included in IS courses and it disappeared. Finally we question what might happen to IS courses into the future.
\end{abstract}

Keywords: Information Systems, Business Computing, Computer Science, Higher Education, Australian Universities, Curriculum, History

\section{Introduction}

This paper looks at how Information Systems (IS) curriculum developed in a Business Faculty over the last forty years in an Australian university. But one might ask: why is this important? The words of George Santayana [1]: "Those who cannot remember the past are condemned to repeat it" provide an answer and help us to understand why history is important. In this case, an important lesson of the past involves the reason for the rise and fall of a number of IS subject areas that covered what was considered to be important material at the time, but which later became mainstream and so not a necessary part of the IS curriculum. Our paper looks at the past, the present and postulates several scenarios for the future of IS courses.

\section{Early Computing in Australia}

Although Computer Science began in Australia's universities of the 1950s, courses in Information Systems (then called Business Computing) did not commence until the 1960s. In this paper we do not address Computer Science but only the development of Information Systems as part of Business degree courses. 
The CSIR Mk1 (CSIRAC) computer was built for the CSIRO $^{1}$ in the late 1940 s and was Australia's first internally stored program computer, and (arguably) the world's fifth [2]. The fact that it was the CSIRO with its connections to the universities and to government that led the way into computing in Australia probably assisted in the early introduction of Computer Science courses into Australian universities [3].

In the late 1950s the Australian Government set out to computerise the operations of the Postmaster General's Department (PMG) and the Department of Defence and it can be argued that this means that the Government was the pacesetter in computing in Australia during the 1960s, and that in many ways the Commonwealth Public Service, rather than commerce in general, paved the way for the introduction of business computing in Australia.

This paper will discuss the beginnings, development and possible future of Information Systems courses at the university level in Australia by looking at these developments in one specific university: Victoria University, Melbourne.

\section{The Beginnings of Computer Science and IS Curricula}

Times change and most people now makes good use of mobile phones and the Internet, but twenty years ago these were just beginning to come into popular use. Sixty years ago a computer was something that few organisations could afford and any idea that people would use a computer at work or even have their own home computer was unthinkable. The advent, first of the mini-computer and later the PC changed everything and in the 1970s computers began to become accessible. Teaching about computers and their use then became important [4].

Computerising the operation of the Department of Defence and the Post Master General's Department created a massive requirement for trained computing personnel [5], but these could not be obtained from overseas as many other developed countries were also computerising government departments. This meant that they had to be trained locally [6]. The universities were then just trying to decide whether computing was a part of mathematics or should be considered as a new discipline $[3,4,7]$ and their courses were quite theoretical and mathematical in nature. Consequently they showed little interest in providing applied courses to cover the establishment and operation of commercial and administrative computing applications [3].

To provide a temporary solution to this problem, in 1960 the Australian Government's Commonwealth Public Service Board set up its own: Programmers in Training (PIT) program [3] and it was this course, as we shall discuss later, that laid the way for Information Systems curriculum in Australia.

The PIT was seen as a "crash computing course" [5] of twelve weeks duration with the goal of alleviating the severe shortage of programmers and other computer professionals in Commonwealth Government departments [6]. The course covered the technical skills associated with computing: Computer Equipment and Techniques, Computer Mathematics (Statistics), Programming, Systems Analysis and Design, but

1 Commonwealth Scientific and Industrial Research Organisation 
also the analytical skills required to design and/or modify systems. The course also had 24 weeks of on-the-job training [5, 8].

The Commonwealth Public Service Board continued running PIT courses until late in the 1960s when responsibility was transferred to the following Colleges of Advanced Education (CAEs) [3]: Caulfield Institute, Bendigo Institute, Canberra CAE and New South Wales Institute of Technology ${ }^{2}$ [5].

These courses set the style for many of the Business Computing (Information Systems) courses later offered in Higher Education in Australia [5]. On the significance of the Commonwealth's initiatives to Higher Education, Pearcey [8:120] notes that: "In many of these institutions, teaching in computing started as a result of the staffing crisis that arose first from the Defence and PMG's projects". These early CAE courses were typically based around subjects such as: Systems Analysis and Design, Database Design, Business Programming (typically done using languages such as COBOL or BASIC) and Systems Implementation. Many also had an introductory Computer Networking unit as well as one handling Computer Architecture. A few years later Footscray Institute of Technology began to offer similar courses.

\section{Methodology}

This study is about the historical beginnings, purpose and development of Information Systems courses at an Australian university and so the research techniques primarily used are those of Curriculum History and Case Study. According to Orlikowski and Baroudi [9], as IS research topics commonly involve the study of organisational systems a case study approach is often quite appropriate. Case study evidence can come from documents, archival records, interviews, direct observation, participantobservation or physical artefacts. In this quasi-historical case, evidence comes from several of these sources and in particular from participant-observation as both authors are long standing academics at Victoria University. The research methods employed can be seen to relate to studies in History [10,11] and also in Curriculum History [1214] which comprise both the analysis of documents and of oral narratives.

\section{IS Curricula at Footscray Institute in the 1970s and 1980s}

The institution that is now Victoria University was formed in the early 1990s from the merger of two formed Colleges of Advanced Education: Footscray Institute of Technology (FIT) and Western Institute (WI). Footscray Institute of Technology [15], formerly Footscray Technical College, was opened in 1916 and Western Institute in the 1980s. In 1991 they merged to form Victoria University (VU). We will begin by considering events at FIT in the 1980s.

Secretarial Studies and Office Automation were the first areas involving some form of computing to be introduced in the early 1970s with an Associate Diploma in

CAEs and Institutes of Technology were, in all but name, polytechnics. 
Secretarial Practice. It was updated in the early 1980s to include: Word Processing, Office Automation, Use of Computer Technology and Electronic Mail.

In 1984 the new Bachelor of Business: Information Management and Communication [16] took its first students. The course was pioneering at the time in stressing that 'information is a critical organisational resource that must be managed effectively and efficiently', rather than one concentrating on 'pure computing' where a study of the technology involved was seen as the priority. Given its background, the course had an office automation/office systems flavour involving a study of office packages and how technology could address the systems life cycle.

At this time Moll and Flood [17] suggested that such courses should not be limited to one discipline, should prepare students with skills for tomorrow and should not be technology bound - their argument being that technological obsolescence occurred too quickly. Garrison [18] also noted that in addition to Office Automation, Information Management courses were emerging out of many disciplines such as the Library and Information Science, Business and Computer Science. Laverty and Sorg [19] identified computer-related knowledge and skills for people charged with the management of information resources as:

- Basic skills allowing use of the computer

- Ability to manage technology as an organisational resource

- Ability to implement IT policy: its promotion, implications of its use and an understanding of its impact on economic, political and the social climate.

As well as a major in Information Management, the degree course had a compulsory minor in more traditional computing areas - programming, systems analysis and systems development. Students were, however, encouraged to do a double major of both Information Management and Computing. At that stage the term 'Information Management' referred to recognition that the information that flowed into, out of and within an organisation was a resource that needed to be managed. The earlier office automation focus thus needed to be updated and so became Information Management.

Around this time, traditional Business Computing (later Information Systems) curricular was beginning to develop and most courses had a core of similar topics which were typically based around subjects related to systems analysis and design, database design, business programming (typically done using third generation such as BASIC, COBOL or Pascal) and systems implementation. Many of these courses also had an introductory computer networking unit which was probably the most technical and close to the discipline of Computer Science. An Associate Diploma in Applied Science (Computing) had been introduced in the late 1970s with Business input as well as from Applied Science in maths and statistics units.

By the late 1980s, there was growing support for the development of a computing course and the Bachelor of Business (Information Technology) was launched with two strands: Information Management and Computing (Systems Development). Students were again encouraged to take subjects from both strands. 


\section{IS Curricula at Western Institute in the late 1980s}

Western Institute (WI) was a CAE newly formed in the mid-1980. In 1989 three courses were offered [20]: Bachelor of Business (Office Administration and Technology), Bachelor of Business (Computing) and Associate Diploma of Applied Science (Computing) - with emphasis on business applications.

In 1989 in order to offer an education in the fundamentals of computing to graduates of other discipline areas such as accounting, management, teaching and office administration, WI introduced the Graduate Diploma in Business Computing. The aim of this new post-graduate course was to offer people currently working in other careers the chance of moving to a career in computing and to offer those currently working with computers the chance to gain a professionally accepted qualification in this area. The course continued at VU after the merger.

\section{Information Systems Curricula at VU from the 1990s - 2000}

In 1992, WI and FIT merged to become Victoria University of Technology ${ }^{3}$, which was one of a number of 'new generation' universities formed in Australia at this time by the 'Dawkins Reforms' [21]. One of the first areas to merge in the new university was the Department of Business Computing at WI and the Business Computing group at FIT (which had been located within the Department of Applied Economics). The new group became the Department of Business Computing. Before the merger FIT had concentrated on Information Management (with some Business Computing) while WI had taken a more traditional line in Business Computing. These streams needed to merge, and in the process several new areas emerged.

Whilst the separate degrees of the two former institutions continued for a few years, by the mid-1990s a new degree, the B.Bus (Business Computing) had been formed with two major streams, Computing and Information Management. This did not require much alteration to the previous units beyond some minor differences of opinion. For instance, at FIT Systems Analysis and Design was taught as two subjects while at WI the two units were taught as Systems Analysis and Systems Design. Whilst the WI model was selected, aspects of the FIT approach were incorporated. This course was delivered across five campuses of the university. A new offering was the B.Bus (Computer Systems Support), which had some overlap with the generic faculty B.Bus degree, but also had some units that were offered to particularly target students wishing to work in the IT support services industry.

The merger of WI and FIT into a new university also provided the chance for the new department to offer postgraduate courses. Higher degree by research programs (Masters and PhDs) were offered from the outset and are still offered today. In the early 1990s the Faculty of Business introduced an MBA program which included a subject on: 'Management Information Systems' which aimed to provide general managers with all they needed to know about computing. A few years later a DBA (Doctor of Business Administration) program (one year coursework and two years thesis) was introduced also containing an Information Systems subject. Each of these

3 Later renamed: Victoria University 
subjects progressed well in the MBA and DBA during the 1990s and early 2000s until the Faculty decided to discontinue them. The argument was that there was no longer any need to teach this material as most of it had become mainstream and students already understood as much about IS as they needed.

A key shift in focus in the second half of the 1990s was the Department of Business Computing changing its name to the School of Information Systems and so creating the B.Bus (Information Systems). Another key shift which occurred late in the 1990s was an increased emphasis within the school on Enterprise Resource Planning (ERP) systems, championed by a particular staff member.

By the early 1990s many of the FIT staff involved in the information management units had left. At the time, one of this paper's authors took over coordination of the information management units, redesigned them from an office automation slant to concentrate more upon the information storage and retrieval aspects of the information life cycle - reflecting the typical approach taken by librarians in their version of information management. The catalyst for this was this author's completion of an M.Bus (IT) at RMIT University, a course which had a heavy librarianship focus. A key focus of the new units was the employment skills of students as 'information professionals'. The idea behind this was to develop students with skills that spanned a number of fields including: the technical skills of traditional computing personnel, an understanding of the concept of information as a resource to be managed within the organisation, understanding how IT could play a strategic role in the organisation and an ability to communicate with other professionals and with senior managers [22, 23]. At the same time the information management units were being redesigned, there were also some key changes on the computing side with the introduction of IT project management and the first visual programming languages.

Project Management is an important aspect of the work of any IT professional but it was not until the 1990s that university courses around the country began to reflect this due to the Australian Computer Society including IT Project Management in its Body of Knowledge for computer professionals [23, 24]. In 1994 a new undergraduate final year subject: Systems Implementation was introduced with a significant project management component. A postgraduate subject in IT Project Management was introduced several years later.

Systems Implementation also included database programming (in dBase IV) and the use of Visual Basic (VB) to create information system front-ends [25 ]. We chose $\mathrm{VB}$ as it was able to easily extract data from a variety of external sources.

\section{IS Curriculum at VU from 2000 - the Present}

In this period a number of significant new curriculum areas emerged, mainly due to the efforts of a small number of academic staff - and some disappeared. The way that this happened bears closely parallels the first stage of Layton's [14] model of curriculum development in which new subjects are seen to justify their existence on grounds of 'pertinence and utility'. 


\subsection{The Rise and Fall of Electronic Commerce}

Towards the end of the 1990s an undergraduate electronic commerce degree was introduced as a new growth area for the university. In the postgraduate area several new e-commerce subjects were introduced in 2000 as increase in business importance of this topic was widely perceived [26, 27]. The new subjects were: Internet Commerce, Building Internet Commerce Systems, Internet Technologies in Business, Small Business Information and Internet Systems and Executive and Mobile Computing $[28,29]$. A little later these subjects were combined into a Masters in eCommerce and also became part of a combined Marketing/e-Commerce masters.

Not long after the 'dotcom' crash, however, student numbers began to drop and reduction in demand for e-business programs and a rationalisation of courses within the university resulted in their discontinuation. The Masters in e-Commerce was thus only offered in 2006 and Masters in e-Commerce/Marketing between 2003 and 2011. This decision was compounded as many of the 'e' aspects of Information Systems had by then become main-stream, and thus part of the main business curricula in Accounting, Management, Economics and other business areas.

\subsection{Enterprise Resource Planning (ERP)}

Around 2000 one of the School's academic staff members developed an interest in the German software company SAP's Enterprise Resource Planning software and soon convinced a number of his colleagues that ERP would be a worthwhile addition to the curriculum. It was first necessary, however, to have access to the software so he used his contacts to convince SAP to provide this. The ERP offerings have remained fairly consistent since the turn of the century, mainly in the postgraduate area and with a few units offered in the undergraduate program. Numbers for the postgraduate programs peaked around 2012, with some drop away since, but are still viable.

\subsection{Consolidation of Offerings, 'Fly By Nighters' and a New Area}

The 2000s saw the consolidation of the three undergraduate information systems offerings into one course and lack of interest in the B.Bus (e-Commerce) program lead to its discontinuation in 2011. In 2006, the Computer Systems Support program was repackaged and redesigned to become the B.Bus (Computer Systems Management) with an increased emphasis on management of IT support areas rather than just working in them. It was discontinued due to lack of numbers in 2013. The B.Bus (Information Systems) continued, but was repackaged and redesigned in 2014 as the B.Bus (Information Systems Management). The program retained its emphasis on the core information systems units of Programming, Systems Analysis and Design and Database, as well as Information Systems Professional and IS Project Management units. The program remains in existence despite having significantly lower enrolled numbers when compared to the previous decade.

After many years of operation, the Graduate Certificate and Graduate Diploma in Business Computing were discontinued in 2008. The M.Bus (Information Systems) course was discontinued in 2013 due to low numbers after being the flagship postgraduate course for over a decade. 
In 2006 two new masters' programs, which targeted more technical aspects of information systems were introduced, being the M.Bus (Network Management) and the M.Bus (Network Application Integration). The aim of the network integration course was to concentrate upon the integration of business information systems both internally and with business partners. At the time, aspects of the design, development, implementation and management of this integration were encompassed under the term Enterprise Application Integration, the Network Management course examining information systems security, management of support services, and network administration. The course aimed to provide students the opportunity to gain a deeper understanding of these issues and the skills to manage in a commercial environment. The courses effectively had only one intake and were discontinued in 2008.

In 2015 as Business Analytics was seen as an important new area, the Information Systems area introduced its first new courses in nine years: the Graduate Diploma and Masters in Business Analytics. These courses aimed to train students for traditional business analyst roles in the modern age with new subjects related to the business analytics area, such as Business Analytics, Business Intelligence Systems and Predictive Analytics. It also shared some subjects with their counterparts in ERP. Some business analytics subjects are also offered as electives in the undergraduate program.

\section{Conclusion: What of the Future?}

We have described how the discipline of Information Systems developed, first in two Colleges of Advanced Education and then in the university created by their merger. During this 40 year period computing has changed dramatically from an area with a small number of Professional Experts to something that everyone now knows something about and makes use of every day. In IS curricula we have seen considerable change as a new curriculum area enters our courses in response to the development of new technologies and business applications and then disappears as this material enters the mainstream and is no longer necessary to be taught as a separate area. We have described a number of instances where this has occurred and, no doubt, there will be more.

The really interesting thing though, and something that must be unique to an area involving rapidly changing technology such as computing, is that from time to time IS course developers must discard much of their content and start again, largely from the beginning with new material [4]. We should now ask: if we look back over the history of IS curriculum development, what lessons have we learned that we might avoid repeating? Perhaps we should not be too quick to introduce a new course until we are sure that there is an industry need and a demand by students and that this will be long lasting. Perhaps we should pay more attention to how industry roles have developed over time with systems analysts becoming general business analysts and then moving into analytics, executive information systems becoming decision support systems and evolving into predictive analytics. Thus, not only do new areas need to be introduced, but existing roles and systems need to be updated through modification and adaptation to account for new approaches and technologies. 
What does this mean for Information Systems departments? Some of the more technical aspects of Information System could merge with Computer Science while others will continue to enter the mainstream and become part of other business subjects. Will there even be a need for a separate discipline of Information Systems into the future? It will certainly be necessary for, perhaps a small number of people, to understand how to analyse business needs and how these could be solved using computing, but the actual construction of these systems in the future is likely to involve even less people than now. Will Information Systems departments continue to educate these people who will analyse business needs and commission the developments of new systems? Time will tell.

\section{References}

1. Santayana, G., The Life of Reason. 1905, New York: Charles Scribner's Sons.

2. McCann, D. and Thorne, P., The Last of the First - CSIRAC: Australia's First Computer. 2000, Melbourne: The University of Melbourne.

3. Tatnall, A., A Curriculum History of Business Computing in Victorian Tertiary Institutions from 1960 - 1985, in Education. 1993, Deakin University: Geelong.

4. Tatnall, A., Curriculum Cycles in the History of Information Systems in Australia. 2006, Melbourne: Heidelberg Press.

5. Maynard, G., Interview on the History of Business Computing. 1990: Melbourne.

6. Tatnall, A., Computer Education and Societal Change: History of Early Courses in Computing in Universities and Schools in Victoria. Information Technology \& People, 2015. 28(4).

7. Gries, D., Walker, T., and Young, P., The 1988 Snowbird Report: a Discipline Matures. Communications of the ACM, 1989. 32(3): p. 294-297.

8. Pearcey, T., A History of Australian Computing. 1988, Melbourne: Chisholm Institute of Technology.

9. Orlikowski, W.J. and Baroudi, J.J., Studying Information Technology in Organizations: Research Approaches and Assumptions. Information Systems Research, 1991. 2(1): p. 1-28.

10. Howell, M.C. and Prevenier, W., From Reliable Sources, An Introduction to Historical Methods. 2001, Ithaca, United States: Cornell University Press.

11. Mahoney, J. and Rueschemeyer, D., Comparative historical analysis in the social sciences. 2003: Cambridge University Press.

12. Goodson, I.F., ed. International Perspectives in Curriculum History. 1988, Routledge: London.

13. Franklin, B.M., Curriculum history: Its nature and boundaries. Curriculum Inquiry, 1977. 7(1).

14. Layton, D., Science as General Education. Trends in Education, 1972(January).

15. Rasmussen, C., Poor Man's University. 1989, Melbourne: Footscray Institute of Technology. 
16. Footscray Institute of Technology, Handbook 1988 Footscray Institute of Technology. 1988, Footscray Institute of Technology: Melbourne.

17. Moll, J.K. and Flood, B.J., Information Science and Information-Related Educational Programs: their Diversity and Accreditation. Journal of the American Society for Information Science, 1988(September): p. 318-322.

18. Garrison, G., Challenges to Information Science Education. Journal of the American Society for Information Science, 1988. 39(5).

19. Laverty, E.P. and Sorg, J.S., Information Technology and Education for the Public Service. International Journal of Public Administration, 1986. 8(4): p. 391-408.

20. Western Institute, Western Institute 1989 Handbook. 1989, Western Institute: Melbourne.

21. Dawkins, J.S., Higher Education Policy Statement. 1988, AGPS: Canberra.

22. Tatnall, A. and Burgess, S., Evolution of Information Systems Curriculum in an Australian University over the Last Twenty-Five Years, in Education and Technology for a Better World, A. Tatnall and A. Jones, Editors. 2009, Springer: Heidelberg. p. 238-246.

23. Burgess, S., Curriculum Planning for Information Management, in Business Information Technology. 1993, Royal Melbourne Institute of Technology: Melbourne.

24. Tatnall, A. and Reyes, G., Teaching IT Project Management to Postgraduate Business Students: a Practical Approach. Journal of Information Technology Education, 2005. 4: p. 153-166.

25. Davey, W. and Tatnall, A. Introducing Object Environments: Cognitive Difficulties. in Software Education Conference: SRIG-ET'94. 1995. Dunedin, New Zealand: IEEE Computer Society Press.

26. Burgess, S. and Tatnall, A. Post Graduate Electronic Commerce Specialisations: an Australian University Case Study. in Innovation Through Information Technology (IRMA). 2004. New Orleans, USA: Idea Group Publishing.

27. Tatnall, A., Groom, C., and Burgess, S. Electronic Commerce Specialisations in MBAs: an Australian University Case Study. in Informing Science and IT Education Conference. 2002. Cork, Ireland: University College Cork.

28. Burgess, S., Tatnall, A., and Darbyshire, P. Teaching Small Business Entrepreneurs about Computers. in EuroPME - Entrepreneurship: Building for the Future. 1999. Rennes, France: Groupe ESC, Rennes.

29. Tatnall, A. and Burgess, S., Experiences in Building and Using DecisionSupport Systems in Postgraduate University Courses. Interdisciplinary Journal of Information, Knowledge, and Management, 2007. 2: p. 33-42. 